\title{
The petrology and geochemistry of kimberlite-like rocks from the Kontozero diatreme, Kola Peninsula, NW Russia
}

\author{
Lyndsey M. MacBride ${ }^{1}$ and Anton R. Chakhmouradian ${ }^{2}$ \\ ${ }^{1}$ Mining Division, Wardrop Engineering Inc., Winnipeg, Manitoba, Canada \\ ${ }^{2}$ Department of Geoogical Sciences, University of Manitoba, Winnipeg, Manitoba, Canada
}

\section{Introduction}

The Kontozero complex is located in the Baltic Shield, Kola Peninsula, Russia (Fig. 1). The complex consists of diverse plutonic and volcanic alkali-ultramafic and carbonatitic rocks filling a caldera-like depression some $8 \mathrm{~km}$ in diameter (Pyatenko and Saprykina, 1981). The volcanics are crosscut by a diatreme that comprises a suite of ultramafic alkaline and carbonate rocks, including kimberlite-like silicocarbonatites (KLS), hypabyssal carbonatites and carbonatite tuffs. The KLS have some petrologic similarities to Group-I kimberlites and were initially identified and logged as kimberlitic rocks, which prompted their detailed reinvestigation. They were characterized and compared with bona fide kimberlites from several North American localites, including the Lac de Gras field in the Northwest Territories, Kirkland Lake field in Ontario and State Line region at the WyomingColorado border.

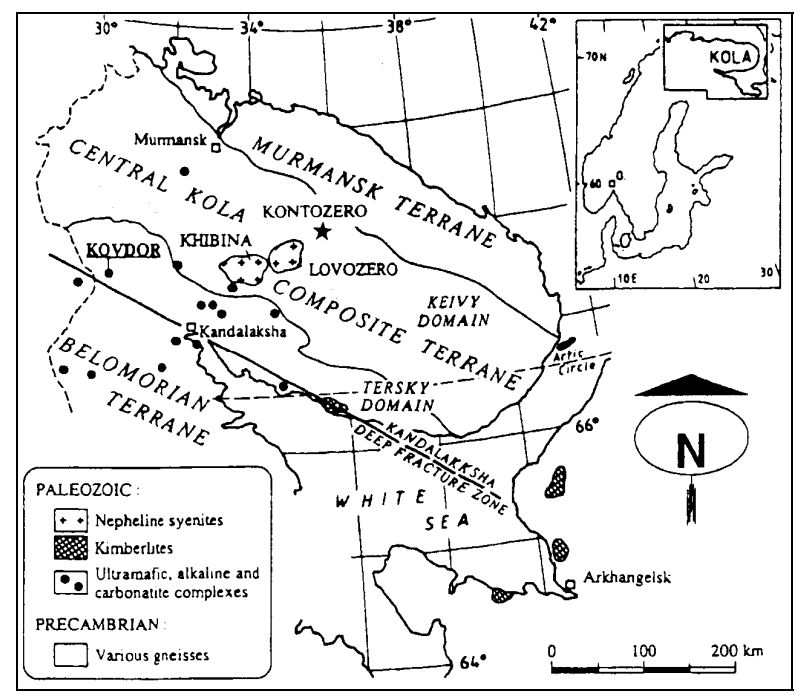

Fig. 1 Schematic structural map of the Kola Peninsula, Russia, showing the Precambrian terranes and Paleozoic alkaline and carbonatite intrusions. The location of the Kontozero complex is marked by a star (after Verhulst et al., 2000).

\section{Mineralogy of kimberlite-like rocks}

The KLS have some textural similarities with kimberlites. They contain pseudomorphed macrocrysts and altered xenoliths in a fine-grained groundmass consisting of poikilitic phlogopite, spinel, perovskite, carbonate, apatite and serpentine (Fig. 2). The macrocrysts are commonly rimmed by "necklaces" of spinel and perovskite crystals. However, the KLS contain a higher proportion of phlogopite, carbonate and apatite in their groundmass and lack the diversity of macrocrysts typically observed in bona fide kimberlites (pyrope, pyroxenes and ilmenite). The macrocrysts in the KLS are consanguineous and consist of partial or complete pseudomorphs after monticellite (Fig. 2), although the presence of olivine in some varieties of these rocks cannot be ruled out. Microxenoliths in the KLS are represented by ultramafic rocks texturally and mineralogically distinct from mantle-derived peridotite nodules in kimberlites. We interpret these microxenoliths to originate from a cumulate unit fragmented and sampled by ascending melts.

Some of the principal constituents of the KLS (e.g., perovskite and phlogopite) show distinct compositional similarities to their counterparts in kimberlites. The phlogopite is indistinguishable in terms of its majorelement chemistry from kimberlitic micas (24-28 wt.\% $\mathrm{MgO}, 12-18$ wt. $\% \mathrm{Al}_{2} \mathrm{O}_{3}$, $\leq 0.5$ wt. $\% \mathrm{TiO}_{2}$; Mitchell, 1995; Masun et al., 2004; Reguir et al., 2008). In common with kimberlitic phlogopite, that from the Kontozero rocks is commonly replaced by serpentine along the margin. Perovskite is low in $\mathrm{Fe}, \mathrm{Nb}, \mathrm{Sr}$ and rare-earth elements $(\leq 2.3,0.5,0.7$ and $2.7 \mathrm{wt} . \%$ respective oxides). In some samples, it is replaced by a cassite-type Ca-deficient oxide phase previously observed in both kimberlites and carbonatites (Chakhmouradian and Mitchell, 2000). Fresh monticellite from Kontozero is distinctly less magnesian and more calcic $[\mathrm{Ca} /(\mathrm{Ca}+\mathrm{Mg})>0.52$; $\mathrm{Mg} /(\mathrm{Mg}+\mathrm{Fe})<0.89]$ than monticellite from hypabyssal kimberlites $(<0.51$ and $>0.90$, 
respectively). Spinel crystals commonly consist of aluminoan (magnesio)chromite (up to 9.9 wt.\% $\mathrm{MgO}$, 7.2 wt. $\% \mathrm{Al}_{2} \mathrm{O}_{3}$ and 43.6 wt. $\% \mathrm{Cr}_{2} \mathrm{O}_{3}$ ) in the core and magnetite in the rim. Most crystals are relatively low in $\mathrm{Ti}$ and rich in $\mathrm{Mn}(\leq 5.2$ and 1.7-3.7 wt.\% respective oxides). Mg-Ti-rich compositions following magmatic trend 1 of Mitchell (1995) are characteristically absent.

Several minerals observed in the Kontozero rocks are inconsistent with their identification as kimberlites and indicate a carbonatitic affinity. These include groundmass $\mathrm{Ca}-\mathrm{Fe}-\mathrm{Ti}$ garnets containing up to 7.6 wt. $\% \mathrm{ZrO}_{2}$ and subsoludis sodic-calcic amphibole.
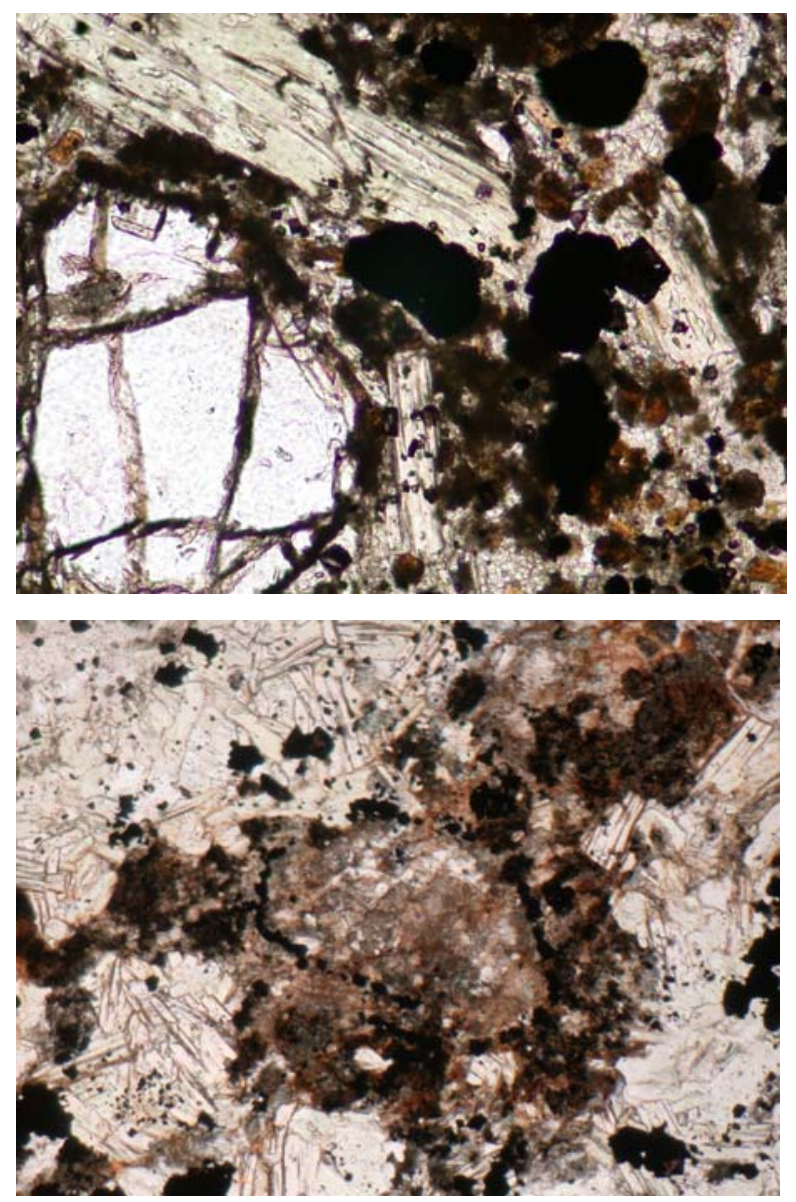

Fig. 2 Photomicrographs (in plane-polarized light) of KLS showing monticellite macrocrysts set in a finegrained groundmass composed of phlogopite, spinel, perovksite, carbonate, apatite and serpentine. Width of the field of view is $2 \mathrm{~mm}$ for (a) and $5 \mathrm{~mm}$ for (b).

\section{Geochemistry of kimberlite-like rocks}

The KLS are characterized by lower $\mathrm{SiO}_{2}, \mathrm{MgO}, \mathrm{Cr}$ and $\mathrm{Ni}$, but higher $\mathrm{CaO}, \mathrm{P}_{2} \mathrm{O}_{5}$ and $\mathrm{CO}_{2}$ contents relative to kimberlites, reflecting the higher modal abundances of calcite and apatite, and the scarcity of olivine and $\mathrm{Cr}$-rich spinels in these rocks. The kimberlites are potassic $\left[\left(\mathrm{K}_{2} \mathrm{O} / \mathrm{Na}_{2} \mathrm{O}\right)_{\text {average }}=4.9\right]$ whereas the KLS from Kontozero are sodic $\left[\left(\mathrm{K}_{2} \mathrm{O} / \mathrm{Na}_{2} \mathrm{O}\right)_{\text {average }}=0.7\right]$.
The trace-element geochemistry of the KLS is compared to that of representative hypabyssal kimberlites from North America in Figure 3. The KLS can be distinguished from kimberlites by their strongly superchondritic $\mathrm{Nb} / \mathrm{Ta}$ and $\mathrm{Ga} / \mathrm{Al}$ values (28-39 and 0.0011-0.0016 respectively in the KLS; 17 and 0.0004 in the average hypabyssal kimberlite). The $\mathrm{Zr} / \mathrm{Hf}$ ratio is variable, but its average value is higher than that in kimberlites (46 vs. 39) in accord with the enrichment of carbonatites in $\mathrm{Zr}$ relative to $\mathrm{Hf}$ worldwide (Chakhmouradian, 2006). The Kontozero samples lack a negative $\mathrm{Sr}$ anomaly typical of kimberlites (Fig. 3a). Both KLS and kimberlites are strongly enriched in light rare-earth elements (LREE) relative to heavy REE (Fig. 3b), but kimberlites show a much steeper REE profile $(\mathrm{La} / \mathrm{Yb}=28$ for the KLS and 196 for the averge hypabyssal kimberlite).
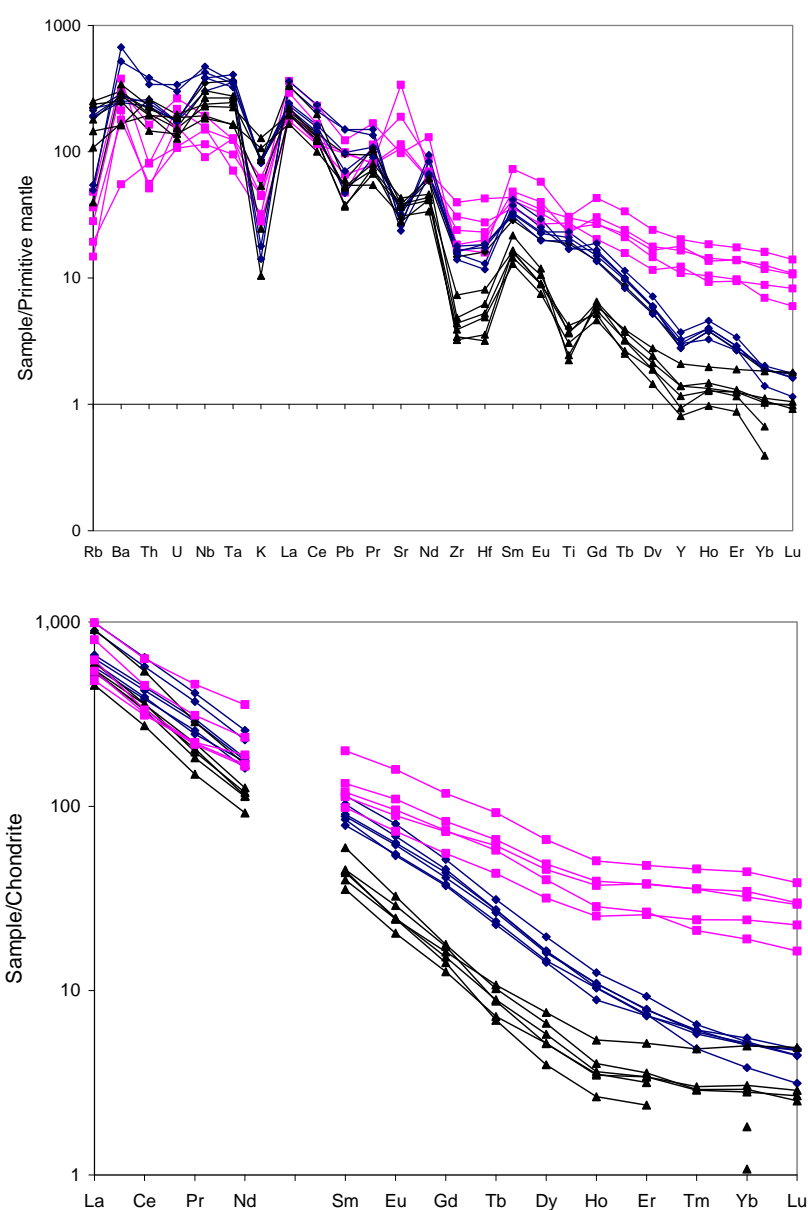

Fig. 3 (a) Primitive-mantle-normalized trace-element abundances and (b) chondrite-normalized REE abundances in the Kontozero KLS (purple squares) compared to North American kimberlites (blue diamonds and black triangles). Normalizing values are from McDonough and Sun (1995). 


\section{Discussion and conclusions}

The kimberlite-like carbonate-rich rocks from the Kontozero diatreme are sufficiently different from kimberlites in terms of their mineralogy and geochemistry to preclude their identification as kimberlites. The observed differences in trace-element geochemistry indicate that the KLS originated from a mantle source significantly different from that producing kimberlitic magmas. The high $\mathrm{Nb} / \mathrm{Ta}, \mathrm{Ga} / \mathrm{Al}$ and $\mathrm{Zr} / \mathrm{Hf}$ values of the KLS imply that their source was a metasomatically modified lherzolite. Their enrichment in $\mathrm{Sr}$ and lower $\mathrm{La} / \mathrm{Yb}$ values relative to kimberlites suggest a more shallow dolomitic source above the magnesite stability field.

\section{References}

Chakhmouradian, A.R., 2006. High-field-strength elements in carbonatitic rocks: Geochemistry, crystal chemistry and significance for constraining the sources of carbonatites. Chemical Geology 235, 138-160.

Chakhmouradian, A.R. and Mitchell, R.H., 2000. Occurrence, compositional variation and alteration of perovskite in kimberlites. Canadian Mineralogist 38, 975-994.

Masun, K.M., Doyle, B.J., Ball, S., Walker, S., 2004. The geology of the Anuri kimberlite, Nunavut, Canada. Lithos 76, 75-97.

McDonough, W.F. and Sun, S.-s., 1995. The composition of the earth. Chemical Geology 120, 223-253.

Mitchell, R.H., 1986. Kimberlites, Orangeites and Related Rocks. Plenum Press, New York.

Pyatenko, I.K. and Saprykina, L.G., 1981. Petrological characteristics of alkaline basaltoids and volcanic carbonatites of the Russian Platform. In Petrology and petrochemistry of ore-bearing igneous formations. Nauka Press, Moscow, 223-255 (in Russian).

Reguir, E.P., Chakhmouradian, A.R., Halden, N.M., Malkovets, V., Yang, P., 2008. Major- and traceelement compositional variation of phlogopite from kimberlites and carbonatites as a petrogenetic indicator. Extended Abstracts CD, 9th International Kimberlite Conference, Frankfurt, Abstract No. 9IKC-A00049.pdf.

Verhulst, A., Balaganskaya, E., Kirnarsky, Y. and Demaiffe, D., 2000. Petrological and geochemical (trace elements and Sr-nd isotopes) characteristics of the Paleozoic Kovdor ultramafic, alkaline and carbonatite intrusion (Kola Peninsula, NW Russia). Lithos 51, 1-25. 